Religion-Related Workplace Discrimination

\title{
Examining the Effects of Exposure to Religion in the Workplace on Perceptions of Religious Discrimination
}

Charges of religion-related employment discrimination have doubled in the past decade. Multiple factors are likely contributing to this trend, such as the increased religious diversity of the US population and the increased interest of employees and some employers in bringing religion to work. Using national survey data we examine how the presence of religion in the workplace affects an individual's perception of religious discrimination and how this effect varies by the religious tradition of the individual. We find that the more an individual reports that religion comes up at work, the more likely it is that the individual will perceive religious discrimination. This effect remains even after taking into account the individual's own religious tradition, religiosity, and frequency of talking to others about religion. This effect is stronger, however, for Catholics, Mainline Protestants, and for the religiously unaffiliated. In workplaces where religion is said to never come up these groups are among the least likely to perceive religious discrimination. Jews, Muslims, Hindus, and Evangelical Protestants are more likely to perceive religious discrimination in the workplace even if they say that religion never comes up at work, which makes the effect of exposure to religion in the workplace weaker for these groups. These results show that keeping religion out of the workplace will largely eliminate perceptions of religious discrimination for some groups, but for other groups the perceptions will remain. 
Religious Discrimination

\section{Examining the Effects of Exposure to Religion in the Workplace on Perceptions of Religious Discrimination}

According to statistics from the US Equal Employment Opportunity Commission, complaints of workplace discrimination involving religion have steadily increased both in number and, over the past twenty years, as a proportion of total complaints ("Charge Statistics"). In 1997, 1,709 religion-related complaints were filed representing $2.1 \%$ of all complaints. In 2013 , this had increased in both number and as a proportion to 3,721 complaints or $4.0 \%$ of all complaints. This issue garnered national attention when the clothing retailer Abercrombie \& Fitch was found liable for discrimination in 2013 when it fired Muslim employee Umme-Hani Khan for refusing to remove her hijab, which violated the company-wide dress code (“Abercrombie” 2013; Equal Employment Opportunity Commission V. Abercrombie \& Fitch Stores, Inc.). Of course, the EEOC statistics only represent cases that are formally filed with authorities.

In a recent review, Ghumman, Ryan, Barclay, and Markel (2013) point to a number of factors that have likely led the increase in religion-related employment discrimination charges. One factor is the increased religious diversity of the American population, including the dramatic growth of the nonreligious population. ${ }^{1}$ While only $5 \%$ of the U.S. population indicated no religious preference in the 1972 General Social Survey, this percentage grew to over $18 \%$ in the 2012 General Social Survey. This "religious none" group is diverse in its beliefs and identities (Baker and Smith 2009a; 2009b), but scholars characterize a sizable subset as "vehemently nonreligious" and "strongly opposed to religion in the public sphere" (2009a: 731). The number

\footnotetext{
${ }^{1}$ Other factors they highlight include legal uncertainties surrounding religion in the workplace and the unique nature of religion relative to race, sex, age, and other categories protected from employment discrimination.
} 
of congregations representing religious traditions outside of Christianity and Judaism has also grown significantly (Wuthnow and Hackett 2003; Wuthnow 2004; Wuthnow 2005). The 2010 U.S. Religious Census: Religious Congregations and Membership Study counted 2,854 Buddhist, 1,625 Hindu, and 2,106 Muslim congregations in the United States (Grammich, Hadaway, Houseal, Krindatch, Stanley and Taylor 2012). While these groups still represent a fairly small proportion of the American population, their market shares have increased over three-fold since the 1970s (Smith 2002).

In addition to this increase in religious diversity, Ghumman et al (2013) also point to the increasing interest of employees and employers in bringing religion andlor spirituality into the workplace, a factor that may also contribute to the rise in discrimination complaints (see also Kelly 2008). Evidence of this interest is seen in numerous media stories of businesses offering mediation groups and classes (Shachtman 2013), corporate prayer groups (Conlin 1999), and workplace chaplains (Banerjee 2006). Some scholars have argued that allowing religion in the workplace can increase employee satisfaction, workforce unity, and organizational performance (Hicks 2003; Mitroff and Denton 1999). While there could be individual or organizational benefits to bringing religion and spirituality up in the workplace, such an action also comes with risks. The presence of formal or informal activities, groups, discussions, or conversations about religion and spirituality in the workplace could produce tension, conflict, and perceived discrimination (Ghumman et al 2013).

Previous research has shown that particular religious identities, such as Muslims and atheists, are more likely to experience andlor perceive religious discrimination in the workplace. ${ }^{2}$ Past research has also shown that an individual's expression of religion, whether through dress,

\footnotetext{
${ }^{2}$ Some of the research we will review looked at experienced or actual discrimination, such as through differential interview rates in field experiments. Other research looks at self-reported discrimination that is more akin to perceptions of discrimination. As we will discuss, our own research is more the latter than the former.
} 
informal conversations, or accommodation requests, is positively related to experiences and perceptions of religious discrimination in the workplace. We build upon this past research by examining the role that a perceived presence of religion in the workplace, independent of an individual's own religious expression or identity, has on perceptions of religious discrimination.

We utilize a national survey of nearly 10,000 US adults. This survey is the only one we are aware of that has asked a question about perceptions of religious discrimination specifically in the workplace to a broad national sample of US adults. ${ }^{3}$ In addition to measures of respondents' religious identity, religiosity, and frequency of talking to others about religion, this survey also asked respondents how often the topic of religion has come up at their place of work. This question serves as the primary measure of interest. We hypothesize that the frequency of religion coming up at work will be positively related to perceptions of discrimination, independent of one's own religious identity, frequency of talking to others about religion, and religiosity. In turn, if an individual reports that religion never comes up at work then we would expect that reports of discrimination would be rare. We also assess whether this hypothesized relationship varies by the religious tradition of the individual. We expect that religious minorities' perceptions of discrimination, in particular the perceptions of non-Christians and the non-religious, will be more significantly impacted by religion coming up at work relative to Christians.

\footnotetext{
${ }^{3}$ The 2003 American Mosaic Project survey (Hartmann, Gerteis and Edgell 2003) did ask a national sample of respondents more generally, "Have you ever experienced any discrimination because of your religion?" Note that this question is not specifically about workplace discrimination. Hammer, Cragun, Hwang, and Smith (2012) did ask a volunteer sample of self-identified atheists specifically about experiences with being "denied employment, promotion, or educational opportunities because of my Atheism." Similarly, Cragun, Kosmin, Keysar, Hammer, and Nielsen (2012) asked a sample of individuals identifying as non-religious in the American Religious Identification Survey whether, "In the past 5 years, have you personally experienced discrimination because of your lack of religious identification or affiliation in any of the following situations: in your workplace." Both of these latter studies are obviously limited in the population that they represent.
} 
Religious Discrimination

\section{Religion-Related Workplace Discrimination}

Religion has been called the "neglected diversity dimension" within the literature on workplace relationships and conflicts, (Gebert, Boerner, Kearney, King Jr., Zhang, and Song (2014: 543). The more voluminous research on race-, sex-, and age-based employment discrimination has shown a wide variety of negative consequences for employers, employees, and broader society resulting from discrimination (Goldman, Gutek, Stein, and Lewis 2006). For instance, research has shown that individuals perceiving or experiencing discrimination have lower job satisfaction, weaker levels of commitment to the employer, and worse physical and mental well-being (Deitch, Barsky, Butz, Chan, and Brief 2003; de Castro, Gee, and Takeuchi 2008; Pavalko, Mossakowski, and Hamilton 2003; Snape and Redman 2003). Much of the research on the consequences of perceived religious discrimination has focused on Muslims, but has been mixed in its results. In a result that the authors described as "puzzling," Jasperse, Ward, and Jose (2012) did not find a significant relationship between perceived discrimination and psychological well-being among a group of Muslim women in New Zealand. Rippy and Newman (2006) found that perceptions of discrimination among the group of Muslims they studied were significantly associated with "subclinical paranoia" but were unrelated to anxiety.

Although research on religious workplace discrimination is sparse in comparison to other forms of workplace discrimination, there has been enough research to identity a couple consistent factors that appear to shape the likelihood that an individual will encounter andlor perceive religious discrimination in the workplace.

\section{$\underline{\text { Religious Identity }}$}


Several resume field experiments have shown that individuals who signal their identity as a Muslim or as an atheist on a resume are less likely to receive further interest from a potential employer (Wallace, Wright, and Hyde 2013; Wallace, Wright, and Hyde 2014). ${ }^{4}$ Evangelical Protestants and Jews, however, were rarely discriminated against in these resume experiments. Highlighting the potential moderating effects of context, Acquisti and Fong (2014) found that a hypothetical Muslim job candidate is less likely than a Christian candidate to receive a call from a potential employer in areas with higher proportions of Republican voters. Although not examining religion explicitly, Widner and Chicoine (2011) found that applicants with an "Arabsounding name" are less likely to receive a call-back, which could connect to assumptions about individuals' religious affiliation.

That Muslims and atheists would experience and perceive discrimination in the workplace at higher rates corresponds with previous research showing relatively negative attitudes towards Muslims and atheists in the U.S. ${ }^{5}$ Putnam and Campbell (2010: 509) summarized survey data showing that "[a]lmost everyone likes mainline Protestants and Jews...[a]lmost everyone likes Catholics...[and] [a]lmost everyone dislikes Muslims...” Similarly, Edgell, Gerteis and Hartmann's (2006: 230) analysis of survey data led them to conclude that "[a]theists are at the top of the list of groups that Americans find problematic in both public and private life, and the gap between acceptance of atheists and acceptance of other racial and religious minorities is large and persistent."

\footnotetext{
${ }^{4}$ Drydakis (2010) conducted a similar study in Greece and find that religious minorities, particularly Jehovah's Witnesses, evangelicals, and Pentecostals, were less likely than Greek Orthodox individuals to receive a job interview even when their applications were identical.

${ }^{5}$ It is important to recognize that this is in relation to the average workplace in the United States. There are undoubtedly specific workplaces or even occupations in which the predominant religion amongst employees is Muslim, atheist, or some other non-Christian tradition. It would be valuable for future research to examine such contexts.
} 
Religious Discrimination

These resume field experiments are powerful in some respects, but they also tend to be limited to one part of the employment process (i.e., the hiring stage). These studies also do not necessarily indicate that individuals of particular groups are more likely to perceive discrimination. To assess perceptions of religious discrimination would require a different method, such as a survey. We are not aware of any nationally representative US survey that has included a question about respondents' experiences with or perceptions of religious discrimination specifically in the workplace other than the survey data we utilize in this research. However, the 2003 American Mosaic Project survey (Hartmann, Gerteis and Edgell 2003) did ask a national sample of respondents more generally, "Have you ever experienced any discrimination because of your religion?" Overall, about one-quarter of respondents said that they had been discriminated against because of their religion. This percentage more than doubles for Muslims, though, which reinforces the expectation that this group in particular might be more likely have perceptions of religious discrimination in the workplace.

\section{$\underline{\text { Religious Expression \& Religiosity }}$}

Independent of particular religious affiliations or identities, past research has pointed to an individual's intentional or unintentional expression of their religious identity as a key factor in experiencing and perceiving religious discrimination. In short, the more an individual makes her religion known to others, the higher her risk of experiencing discrimination. This expectation has parallels in research showing that an individual's level of gender nonconformity (Roberts, Rosario, Slopen, Calzo and Austin 2013; Miller and Grollman 2015; Dean 2013) or her “openness" and disclosures to others about being gay, lesbian, or bisexual (D'Augelli, Pilkington, and Hershberger 2002) increases the likelihood of being discriminated against, 
bullied, or victimized. And there is similar research in the area of ethnic discrimination suggesting that individuals with accents or limited English language skills might also be at increased risk of discrimination and victimization, as this serves as a type of involuntary expression of ethnicity (Hein 2000).

Religious expression in the workplace could come in various implicit and explicit forms. It could involve informally discussing religion with one's co-workers, neighbors, or strangers. It could consist of praying in public spaces or displaying religious symbols. It could involve requesting accommodations for religious practice. Religious expression could involve wearing religiously distinctive clothing or jewelry (Boynton 1989; McDannell 1995; Arthur 1999), or abstaining from certain behaviors, such as eating or drinking certain foods, due to religious beliefs. Because we would expect that an individual's level of religious expression would be strongly correlated measures of his or her religiosity, we would expect the later to be a proxy of the former. Indeed, a study of Muslims found that more general measures of religiosity (e.g., prayer frequency, religious service attendance frequency, self-reported religiosity) were positively related to perceptions of discrimination (Ghaffari and Çiftçi 2010).

A handful of field experiments have focused on the role of religious expression or religious identity-markers. For example, King and Ahmad's (2010) sent observers and confederates into the field to inquire about job openings. In one condition the female confederate would wear the Muslim-identified clothing of an abbaya and a hijab. In the other condition the female confederate would wear shoes, pants, and a shirt. The confederate and the observer rated the interactions with the employer, and the interactions were also recorded through a device in the confederate's purse. The results showed that when wearing the Muslim-identified clothing the interactions were shorter and less positive. 
Similar conclusions regarding the role of religious expression in increasing discrimination risk can be found in Ghumman and Jackson's (2010; see also Ghumman and Jackson 2008) study of Muslim women. The researchers asked the women if they wear a hijab or not. They then randomly provided the participants with job descriptions and asked how likely the women felt it was that they would receive the job if they were to apply for it. The results showed that women who wore the hijab had lower expectations about receiving the job, especially if it was a job where she would be interacting with the public. Mythen, Walklate and Khan (2009: 749) conducted interviews with young Muslims in the United Kingdom and found that many of their respondents intentionally avoided wearing a hijab or other religiously distinctive clothing, as a strategy to "play down their Muslimness" and avoid discrimination. Peek (2010: 57) also found that Muslim women who wore a headscarf were more likely to be victimized and discriminated against, "which was undoubtedly a consequence of their visibility."

Although much of the previous research has focused on Muslims, there is at least some indirect evidence that the intensity of an individual's religious identity, and therefore the likelihood and amount of public religious expression, is related to perceptions of discrimination. Interestingly, some of this evidence comes from a study of the non-religious. Cragun, Kosmin, Keysar, Hammer and Nielsen (2012) examined a sample of individuals who held no religious affiliation. They found that individuals who identify themselves as atheist or agnostic were twice as likely to report discrimination in the workplace compared to those who simply describe themselves as having no religion (see also Hammer, Cragun, Smith, and Hwang 2012). ${ }^{6}$ This suggests that the more pronounced an individual's religious identity, or in this case non-religious identity, the more likely they are to perceive discrimination. This could be because an individual

\footnotetext{
${ }^{6}$ The specific question they asked was, "In the past 5 years, have you personally experienced discrimination because of your lack of religious identification or affiliation in any of the following situations: in your workplace." They did not ask this question of the religious respondents in their sample.
} 
who feels more strongly about their religious views are more likely to express those views either implicitly or explicitly.

\section{Influence of Religion Coming Up in Workplace}

As is clear in the above review, past research on religious discrimination in the workplace has highlighted the effects that particular religious identities and an individual's level of religious expression have on experiences with and perceptions of religious discrimination. What this past research has not examined as clearly is the effect that a general presence of religion in the workplace can have on perceptions of discrimination independent of an individual's own religious tradition and religious expression. For instance, if religion is a frequent topic of conversations at work or if there are religious groups meeting in the lunchroom, does this affect the likelihood of perceiving religious discrimination even if an individual is not personally expressing religion him- or herself or part of a particular religious tradition?

Although this question is distinct from the question of how one's own religious expression would increase the likelihood of experiencing and perceiving religious discrimination, its logic is in many ways an extension of that question. If a person expresses religious views in an informal workplace conversation or participates in something like a lunchroom Bible study group we would expect it to increase the risk of discrimination. If the person had not engaged in this religious expression then they would have been less exposed to religious discrimination, as others would have been less likely to know the individual's religious beliefs or identity.

While that informal conversation about religion or study group was taking place, however, it is possible that a different person not participating in the religious expression 
overheard or observed something that they perceived as discriminatory. Or, they might perceive the very existence of this conversation or group as creating a discriminatory environment. In short, while one's own religious expression would be expected to increase the risk of perceiving religious discrimination, the religious expression by others could also be expected to increase the risk of perceiving religious discrimination independent of one's own expression or religious tradition.

\section{Data}

The data for this research were produced from a survey utilizing the GfK KnowledgePanel, a nationally representative online panel of over 50,000 individuals. The KnowledgePanel has been utilized in numerous research articles published in top social science journals (e.g., Doan, Loehr and Miller 2014; Pedulla and Thebaud 2015), and Chang and Krosnick (2009) found that representative online panels provide the representativeness of random-digit dialing while reducing measurement error, survey satisficing, and social desirability response bias. Panel members are selected into the panel through an address-based sampling frame. Individuals without internet access are provided a computer and internet service to participate in the panel. Our survey randomly selected 16,746 panel members from the overall KnowledgePanel. Of those selected, 10,241 completed the survey. After removing cases with missing data, our final analytic sample below consists of 9,723 respondents. We utilize a poststratification weight that adjusts for non-response patterns based on population benchmarks from the October 2012 Current Population Survey. ${ }^{7}$

\footnotetext{
${ }^{7}$ The specific benchmarks are for gender, race and Hispanic ethnicity, education, household income, region, household internet access, and household primary language.
} 
Religious Discrimination

\section{Outcome Measure}

Although workplace discrimination was not a primary focus of the survey used in this research, the survey did contain a question regarding respondents' experiences with religious discrimination in the workplace. Specifically, this question asked, "How often have you felt discriminated against at your place of work because of your religious beliefs?" Responses offered were 1) Never, 2) Rarely, 3) Sometimes, 4) Very often. It is important to recognize what this question does and does not represent. It does not represent a legal definition of employment discrimination. It is more akin to a criminal victimization survey in which respondents report on their perception that they have been the victim of a crime. This does not mean that there is no value in assessing such perceptions. As with crime, individuals might be hesitant to officially report employment discrimination, which makes such victimization or perception surveys important complements to official statistics.

It would obviously be desirable to have this question followed up with questions concerning the details of any perceived discrimination, such as the type and context of the discrimination (e.g., was it in regards to hiring, promotion, accommodations?). Such questions were unfortunately not asked in the survey, although this is not surprising given that the survey was not dedicated to assessing religion-related employment discrimination. We argue, though, that this measure still presents a unique and valuable assessment of individuals' frequency of experiences with workplace religious discrimination.

\section{Respondent's Religious Tradition}

The survey included a series of questions to assess the respondents' religious tradition. These questions began with a broad affiliation question asking, "Religiously, do you consider 
yourself to be Protestant, Catholic, Jewish, Mormon, Muslim, not religious, or something else?", Respondents selecting Protestant, Just a Christian, or Something Else were then asked follow-up questions to narrow their affiliation to a specific denomination, if possible. We used a common classification system to place Protestant respondents into either an Evangelical, Mainline, or Black Protestant category (Steensland et al 2000). We also include indicators for Catholic, Jewish, Mormon, Muslim, Hindu, Other Eastern (Buddhist, Sikh, Jain, Baha'i), Not Religious, Agnostic, Atheist, and Something else.

\section{Respondent's Religious Expression \& Religiosity}

The survey contained one question that can help us measure religious expression by respondents. The question asks about religious expression more broadly by asking respondents, "In the past month, about how often have you talked with people of a different religion about your religious views, whatever they may be." Offered responses were 1) Not at all, 2) One or two times, 3) Three or four times, 4) Five or more times. Although this question does not specifically refer to workplace conversations, we are making an assumption that if a person is likely to engage in such conversations in general then they will be more likely to engage in the conversations at work. Note that the wording of this question would be applicable to the nonreligious, as they could easily talk to others about their lack of religion.

The survey also included several measures of religiosity. These measures are not directly measuring religious expression in the same way as the prior question, but we expect that they will serve as an indirect proxy for the likelihood of religious expression beyond that measure. For instance, attending religious services more frequently could increase the chances that a

\footnotetext{
${ }^{8}$ The offered choices included thirteen options, including Just a Christian, Eastern Orthodox, Buddhist, Hindu, Agnostic, and Atheist, in addition to those mentioned in the question wording.
} 
person mentions going to those services in the workplace. Similarly, if a person reads religious texts frequently then they might keep such a text on their desk. We include four measures to assess respondents' religiosity. ${ }^{9}$ These items mirror questions asked on other national surveys, such as the General Social Survey (Smith, Marsden, and Hout 2016) and the Baylor Religion Survey (Baylor University 2007). The first is a question that simply asks the respondent to rate their religiosity. This question asked, "To what extent do you consider yourself a religious person? Are you very religious, moderately religious, slightly religious, or not religious at all?" The next measure asked for the respondents' frequency of attending religious services by asking, "How often do you attend religious services?" Nine potential responses were offered ranging from "Never" to "More than once a week." We also include a measure that asked, "About how often do you pray?" Eleven potential responses were offered raging from "Never" to "Several times a day." Finally, we include a question asking, "Outside of attending religious services, about how often do you read the Bible, Koran, Torah, or other sacred book?" Nine responses were offered ranging from "Never" to "Several times a week.",10

\section{Religion in the Workplace}

Past research has shown that certain religious traditions and greater religious expression are at higher risk of discrimination in the workplace. The goal of this research is to examine the impact of religion coming up in the workplace independent of an individual's own religious expression or religious tradition. Fortunately, the survey utilized here included a question asking

\footnotetext{
${ }^{9}$ One limitation of these religiosity measures is that they are most applicable to the religious population. For the non-religious it might be ideal to have questions that might serve as similar proxies. These questions might ask about the frequency of visiting certain websites or reading certain books associated with, say, atheism.

${ }^{10}$ Since these religiosity items are clearly going to be correlated with each other, we examined variance inflation factors to assess for potential collinearity problems. None of these inflation factors were above 3.0, which is well below the typical level of concern (Regression with Stata, 2016).
} 
Religious Discrimination

respondents, "How often has the topic of religion come up at your place of work?" Responses offered were 1) Never, 2) Rarely, 3) Sometimes 4) Very often. After we take into account the measures discussed above, this question will allow us to examine how the presence of religion as a topic in the workplace affects perceptions of religious discrimination.

\section{Other Controls}

We account for several other social and demographic variations in our analyses, including education, income, age, sex, and race. Education is measured on a four point scale: 1) Less than high school degree, 2) High school degree, 3) Some college, 4) Bachelor's degree or more. Household income is measured on a nineteen point scale ranging from "Less than $\$ 5,000$ " to " $\$ 175,000$ or more." The age measure contains seven categories: $18-24,25-34,35-44,45-54$, 55-64, 65-74, 75 and older. Sex is measured dichotomously where 0 represents men and 1 represents women. Race is measured with four categories representing White Non-Hispanics, Black Non-Hispanics, Other Non-Hispanics, and Hispanics. In the analyses below the White Non-Hispanic group serves as the reference category.

\section{〈INSERT TABLE 1 ABOUT HERE〉}

\section{Results}

Descriptive statistics for all measures are shown in Table 1. Most survey respondents did not report any workplace religious discrimination. Looking at the frequency of responses, we find that $83 \%$ state they have never felt discriminated against at work due to their religion, $10 \%$ say this has occurred rarely, $6 \%$ say this has happened sometimes, while only $1 \%$ of respondents say they have been discriminated against at work very often due to religion. Of course, we would 
Religious Discrimination

not really expect the majority of Americans to report religion-related discrimination, so the fact that $83 \%$ do not report such discrimination is not surprising.

Figure 1 shows the percentage of respondents in our survey data reporting at least some experience with religion-related discrimination by religious tradition. We see that the highest rate of reporting discrimination is found among Muslims (44\%) and Hindus (41\%). Jews also appear more likely to say they have experienced discrimination at work (30\%). Looking at the Christian groups, we find that Evangelical Protestants appear more likely to report discrimination in the workplace compared to other Protestants and Catholics. We also see that self-identified atheists have higher reported rates of discrimination than those who identify as agnostic or simply as "not religious."

\section{<INSERT FIGURE 1 ABOUT HERE>}

Having examined our data with some initial descriptive analyses, we now turn to our full analytical models. These are shown in Table 2. Because most respondents report never having experienced religious discrimination, we combine the other three categories into a "more than never" response. As a result, we use logistic regression analysis to predict our outcome where $0=$ never experiencing religion-related workplace discrimination and $1=$ experiencing at least some religion-related workplace discrimination. The table shows odds ratios, so that numbers above 1 represent an increase in the odds of reporting workplace religious discrimination and numbers below one represent a reduction in the odds.

In Model 1 we only include our control variable and our key measure of how often religion is said to come up as a topic in the respondent's workplace. The results show that the odds of a respondent perceiving religious discrimination in his or her workplace are greater as the frequency of religion coming up at work increases. This is what we expected, although it is 
not clear at this point in the analysis whether this is independent of the respondent's own religious expression, religiosity, and religious tradition. Looking at the control measures we see that education is positively related to perceptions of religious discrimination, while income is negatively related to such perceptions. Older respondents and female respondents also show significantly lower odds of perceiving religious discrimination relative to younger respondents and male respondents, respectively. Compared to white non-Hispanic respondents, those in the other non-Hispanic category have higher odds of perceiving religious discrimination. This could reflect the possibility that some respondents experience discrimination based on their race or ethnicity because they are perceived to be of a certain religion.

Model 2 enters our measures for the respondents' religious tradition, frequency of talking to others about religion, and religiosity. Remember that the latter is thought of as an additional proxy for the likelihood of religious expression. Examining the religious tradition indicators we find that, relative to evangelical Protestants, Jewish, Muslim, Hindu, and atheist respondents have significantly greater odds of perceiving religious discrimination in their workplace. Mainline and black Protestants, on the other hand, have significantly lower odds of perceiving religious discrimination compared to evangelicals. Catholic, Mormon, not religious, agnostic, and adherents of other Eastern (i.e., Buddhist, Sikh, Jain, Baha'i) or other religious traditions do not significantly differ from evangelicals.

As expected, the measure of how often the respondent talks to others about religion is significantly associated with greater odds of perceiving religious discrimination. A respondent's frequency of attending religious services and his or her frequency of reading sacred texts are also both positively associated with perceptions of religious discrimination. Such behaviors could lead respondents to explicitly (e.g., ask for a day off work for a religious holiday) or implicitly 
(e.g., leave a sacred text in their briefcase or purse) express their religion in the workplace. Interestingly, however, a respondent's frequency of prayer has a significant negative association with perceiving religious discrimination. In other words, the most frequently an individual prays the less likely she is to perceive religious discrimination. One possibility for this unexpected effect is that prayer serves as a coping mechanism that lowers the odds of a person feeling discriminated against even if they might actually experience potential discrimination. Indeed, there is research which suggests that religious behaviors can reduce the impact of discrimination experiences (e.g., Bierman 2006).

Most important given the focus of this research is that the measure of religion coming up at work remains significantly associated with perceptions of religious discrimination even after we account for all of the other measures. This means that the presence of religion as a topic at work increases an individual's likelihood of perceiving religious discrimination regardless of what his or her own religious identity is or how much he directly or indirectly expresses his religious identity, beliefs, or behaviors.

In our final model we are analyzing whether the effect of religion coming up as a topic at work on perceptions of religious discrimination varies depending on the religious tradition of the respondent. As we stated at the beginning of this paper, we expect that religion coming up at work will have a greater impact on perceptions of religious discrimination for non-Christians and the non-religious. To assess this question we include a series of interaction terms in Model 3 between respondent's religious tradition and the frequency of religion coming up at the respondent's work.

<INSERT TABLE 3 ABOUT HERE> 
Religious Discrimination

The results from model 3 somewhat support our expectation. The effect of religion coming at work on perceptions of religious discrimination is greater for mainline Protestants, Catholics, adherents to Eastern traditions (Buddhist, Sikh, Jain, Baha'i), those saying they are not religious, agnostics, atheists, and those belonging to some other religious tradition. The effects for Muslims, Hindus, Jews, Mormons, and black Protestants do not significantly differ from the effect for evangelical Protestants. To examine these findings in more detail we computed a series of predicted probabilities based on the findings of Model 3. In computing these probabilities we varied the religious tradition and the frequency of how often religion comes up at work while holding all of the other measures at their respective means. The probabilities are shown in Table 4.

The first column shows the probability that an individual will perceive religious discrimination in a workplace where religion never comes up as a topic. We see that in such a workplace, about 25 percent of Jews and Muslims are predicted to perceive religious discrimination. About 10 percent of evangelical Protestants, Mormons, and Hindus are predicted to perceive religious discrimination in such a workplace. About 5-7 percent of other Protestants, Catholics, the not religious, and atheists perceive religious discrimination in this context. That Jews and Muslims have such high probabilities of perceiving religious discrimination even when religion is never coming up as a topic is something that we will discuss later.

The second column shows the probabilities for a workplace in which religion is said to come up very often. We see that the probability of perceiving religious discrimination increases in such a workplace for all the religious traditions. The size of this increase, however, varies substantially. Atheists are 12 times as likely to perceive religious discrimination in a workplace where religion comes up very often compared to a workplace where religion never comes up. 
Religious Discrimination

Agnostics and adherents of the other Eastern traditions are 28 times as likely. The likelihood for Muslims, Mormons, and evangelicals only doubles, but remember that these groups were more likely to perceive religious discrimination even when religion was said to never come up at work. If we look at the overall probabilities we see that in the "very often" workplaces that Hindus, agnostics, and atheists are the most likely to perceive religious discrimination followed by Jews, Muslims, the not religious, and adherents of other Eastern traditions. Protestants and Mormons are among the least likely to perceive religious discrimination in a workplace where religion comes up very often. It is possible that Protestant-related content is what tends to come up the most in the average US workplace, and such content is less likely to be seen as discriminatory by Protestants and Mormons.

\section{<INSERT TABLE 4 ABOUT HERE>}

\section{Discussion}

Past research has shown that specific religious identities, particularly Muslim and atheist, are at higher risk for experiencing andlor perceiving religious discrimination in the workplace. Past research has also shown that expressing religious identities in one way or another can increase the risk of experiencing andlor perceiving religious discrimination in the workplace. The research presented here took this past work a step further by asking how the presence of religion as a topic in the workplace affects perceptions of religious discrimination independent of a person's own religious identity or religious expression. We examined this issue using the only nationally representative survey we are aware of to include a question specifically about respondents' perceptions of religious discrimination in the workplace.

The results of our analysis reveal that the frequency with which religion comes up in the workplace is positively associated with perceptions of religious discrimination. This association 
remains even after accounting for an individual's religious tradition, expression, and religiosity. In short, the presence of religion as a topic in the workplace appears to present an independent risk of perceiving religious discrimination. Indeed, as we saw in Table 4, moving from a workplace where religion never comes up to a workplace where religion often does almost triples the probability that an individual will perceive religious discrimination. The impact of religion coming up at work on perceptions of discrimination is greater for mainline Protestants, Catholics, adherents of other Eastern traditions (i.e., other than Muslim and Hindu), those who are not religious, agnostics, and atheists. This greater impact is, in part, a function of these groups being unlikely to perceive religious discrimination in a workplace where religion never comes up.

Our analyses showed that, even when religion never comes up at work, some groups-especially Muslims and Jews-- were still much more likely to perceive religious discrimination. What might be causing these perceptions in the absence of religion coming up at work? One explanation might simply be that we are not able to measure all of the mechanisms that are producing discrimination experiences for these groups. Individuals belonging to these groups might have greater visibility in the average American workplace since they do not practice Christianity, the dominant US religious tradition. This visibility might lead them to encounter discrimination even if religion is not explicitly coming up as a topic at work and they are not talking to others about religion or indirectly expressing their religion.

It is also possible that beliefs held within these groups about how they are viewed by the larger American public shape perceptions of discrimination. That is, individuals belonging to groups that have long experienced discrimination and hostility, such as Muslims and Jews, might be primed to perceive discrimination. Individuals belonging to religious groups that have a 
history of being discriminated against could approach the workplace with more anxiety and fear, which then leads to perceiving discrimination independent of actual events. Research has shown that individuals with high "negative affectivity"-characterized by anxiety, fear, anger, and hostility-tend to report higher levels of workplace harassment, discrimination, or victimization (Aquino, Grover, Bradfield and Allen 1999). One potential mechanism for this pattern is that negative affectivity "might predispose individuals to perceive the presence of harassment regardless of whether harassment has actually occurred," since these groups are used to experiencing harrassment (Bowling and Beehr 2006: 1005).

A third, not unrelated, possibility is that individuals belonging to religious traditions that have greater fears of being a victim of workplace religious discrimination feel greater pressure to hide or suppress their religious identity and beliefs. Ironically, this suppression may actually produce feelings of discrimination independent of actual experiences with discrimination. Madera, King, and Hebl (2012) found that the more a worker reports various identity suppression strategies (e.g., "I hide emblems that would reflect this identity at work;" "I try not to use the language, vernacular, or speech style of this identity at work;" and so on), the more likely they are to perceive discrimination in the workplace.

The finding that the frequency with which religion comes up at work increases perceptions of religious discrimination for all individuals presents a dilemma for those whose aim it is to prevent or reduce such discrimination. One obvious implication is that workplaces simply should not allow religion to come up in any formal or informal way. Indeed, as our results show, if religion is eliminated as a topic in the workplace then all individuals will have a reduced likelihood of perceiving religious discrimination. Such a policy, even if somehow legal and feasible, would likely come with its own costs to employee morale and workplace climate 


\section{Religious Discrimination}

(Hicks 2003; Mitroff and Denton 1999), since other research show that religious or spiritual expression in the workplace can under certain conditions increase employee productivity and morale. One likely important moderating factor that we cannot account for with our data is the context and climate in which religion is coming up as a topic within respondents' workplaces. Theory and research emphasize the importance of equal standing among individuals, common goals, cooperative efforts, as well as support from authorities for intergroup contact all a necessary for positively shaping attitudes (Allport 1954; Pettigrew 1998). For instance, we do now know whether the respondent's workplace actively encourages religious tolerance, acceptance, or expression. Measuring and accounting for the moderating influence of such workplace factors could provide a guide for how religion can be allowed to come up within the workplace without leading to increased perceptions of discrimination. 
Religion-Related Workplace Discrimination

\section{References}

“Abercrombie \& Fitch Liable for Religious Discrimination in EEOC Suit, Court Says.” 2013. San Francisco, CA: U.S. Equal Employment Opportunity Commission. Retrieved February 24, 2015 (http://eeoc.gov/eeoc/newsroom/release/9-9-13.cfm).

Acquisti, Alessandro and Fong, Christina M. 2014. “An Experiment in Hiring Discrimination Via Online Social Networks.” Available at Social Science Research Network http://dx.doi.org/10.2139/ssrn.2031979

Allport, Gordon W. 1954. The Nature of Prejudice. Reading, MA: Addison-Wesley.

Aquino, Karl, Steven L. Grover, Murray Bradfield, and David G. Allen. 1999. "The Effects of Negative Affectivity, Hierarchical Status, and Self-Determination on Workplace Victimization.” Academic of Management Journal 42(3): 260-272.

Arthur, Linda B. 1999. Religion, Dress and the Body. New York: Bloomsbury Academic. Baker, Joseph O’Brian and Buster Smith. 2009a. "None Too Simple: Examining Issues of Religious Nonbelief and Nonbelonging in the United States.” Journal for the Scientific Study of Religion 48(4):719-733.

Baker, Joseph O. and Buster Smith. 2009b. "The Nones: Social Characteristics of the Religiously Unaffiliated." Social Forces 87(3): 1251-1263.

Baylor University. 2007. The Baylor Religion Survey, Wave II. Waco, TX: Baylor Institute for Studies of Religion [producer].

Banerjee, Neela. 2006. “At Bosses’ Invitation, Chaplains Come into Workplace and Onto Payroll." The New York Times

Bierman, Alex. 2006. "Does Religion Buffer the Effects of Discrimination on Mental Health? Differing Effects by Race.” Journal for the Scientific Study of Religion 45(4): 551-565. 
Bowling, Nathan A. and Terry A. Beehr. 2006. “Workplace Harassment from the Victim's Perspective: A Theoretical Model and Meta-Analysis.” Journal of Applied Psychology 91(5): 998-1012.

Boynton, Linda Louise. 1989. "Religious Orthodoxy, Social Control and Clothing: Dress and Adornment as Symbolic Indicators of Social Control among Holdeman Mennonite Women." Presentation at the Annual Meeting of the American Sociological Association.

Chang, Linchiat and Jon A. Krosnick. 2009. "National Surveys Via RDD Telephone Interviewing Versus the Internet: Comparing Sample Representativeness and Response Quality.” Public Opinion Quarterly 73(4): 641-678.

“Charge Statistics.” U.S. Equal Employment Opportunity Commission.

\section{http://eeoc.gov/eeoc/statistics/enforcement/charges.cfm}

Conlin, Michelle. 1999. "Religion in the Workplace: The Growing Presence of Spirituality in Corporate America.” Business Week

Cragun, Ryan T., Barry Kosmin, Ariela Keysar, Joseph H. Hammer, and Michael Nielsen. 2012. “On the Receiving End: Discrimination toward the Nonreligious in the United States." Journal of Contemporary Religion 27(1): 105-127.

de Castro, Arnold B, Gilbert C. Gee, and David T. Takeuchi. 2008. "Workplace Discrimination and Health Among Filipinos in the United States." American Journal of Public Health 98(3): 520-526.

Dean, James Joseph. 2013. "Heterosexual Masculinities, Anti-Homophobias, and Shifts in Hegemonic Masculinity: The Identity Practices of Black and White Heterosexual Men.” The Sociological Quarterly 54(4): 534-560. 
Deitch, Elizabeth A., Adam Barsky, Rebecca M. Butz, Suzanne Chan, and Arthur P. Brief. 2003. "Subtle Yet Significant: The Existence and Impact of Everyday Racial Discrimination in the Workplace." Human Relations 56(11): 1299-1324.

D’Augelli, Anthony R., Neil W. Pilkington and Scott L. Hershberger. 2002. "Incidence and Mental Health Impact of Sexual Orientation Victimization of Lesbian, Gay, and Bisexual Youths in High School.” School Psychology Quarterly 17: 148-167.

Doan, Long, Annalise Loehr, and Lisa R. Miller. 2014. "Formal Rights and Informal Privileges for Same-Sex Couples: Evidence from a National Survey Experiment.” American Sociological Review 79(6): 1172-1195.

Drydakis, Nick. 2010. "Religious Affiliation and Employment Bias in the Labor Market." Journal for the Scientific Study of Religion 49: 477-493.

Edgell, Penny, Joseph Gerteis, and Douglas Hartmann. 2006. “Atheists as 'Other': Moral Boundaries and Cultural Membership in American Society.” American Sociological Review 71(2):211-234.

Equal Employment Opportunity Commission v. Abercrombie \& Fitch Stores, Inc. Supreme Court of the United States. No 14-86. Argued 25, 2015-Decided June 1, 2015.

Gebert, Diether, Sabine Boerner, Eric Kearney, James E. King Jr., Kai Zhang, and Lynda Jiwen Song. 2014. "Expressing Religious Identities in the Workplace: Analyzing a Neglected Diversity Dimension.” Human Relations 67(5): 543-563.

Ghaffari Azadeh and Ayşe Çiftçi. 2010. "Religiosity and Self-Esteem of Muslim Immigrants to the United States: The Moderating Role of Perceived Discrimination.” The International Journal for the Psychology of Religion 20(1): 14-25. 
Ghumman, Sonia and Linda Jackson. 2008. "Between a Cross and a Hard Place: Religious Identifiers and Employability.” Journal of Workplace Rights 13(3): 259-279.

Ghumman, Sonia and Linda Jackson. 2010. “The Downside of Religious Attire: The Muslim Headscarf and Expectations of Obtaining Employment." Journal of Organizational Behavior 31(1): 4-23

Ghumman, Sonia, Ann Marie Ryan, Lizabeth A. Barclay, and Karen S. Markel. 2013. "Religious Discrimination in the Workplace: A Review and Examination of Current and Future Trends.” Journal of Business and Psychology 28(4): 439-454.

Goldman, Barry M., Barbara A. Gutek, Jordan H. Stein, and Kyle Lewis. 2006. "Employment Discrimination in Organizations: Antecedents and Consequences.” Journal of Management 32(6): 786-830.

Grammich, Clifford, Kirk Hadaway, Richard Houseal, Dale E. Jones, Alexei Krindatch, Richie Stanley, and Richard H. Taylor. 2012. 2010 U.S. Religion Census: Religious Congregations \& Membership Study. Association of Statisticians of American Religious Bodies.

Hammer, Joseph H., Ryan T. Cragun, Jesse M. Smith, and Karen Hwang. 2012. "Forms, Frequency, and Correlates of Perceived Anti-Atheist Discrimination.” Secularism and Nonreligion 1: 43-58.

Hartmann, Doug, Penny Edgell and Joseph Gerteis. American Mosaic Project: A National Survey on Diversity. Datafile and codebook. Accessed at www.thearda.com Herberg, Will. 1955. Protestant-Catholic-Jew: An Essay in American Religious Sociology. Chicago: University of Chicago Press. 
Hicks, Douglas A. 2003. Religion and the Workplace: Pluralism, Spirituality, Leadership. Cambridge: Cambridge University Press.

Jasperse, Marieke, Colleen Ward, and Paul E. Jose. 2012. “Identity, Perceived Religious Discrimination, and Psychological Well-Being in Muslim Immigrant Women.” Applied Psychology 61(2): 250-271.

Kelly, Eileen P. 2008. “Accommodating Religious Expression in the Workplace.” Employee Responsibilities and Rights Journal 20(1): 45-56.

King, Eden B. and Afra S. Ahmad. 2010. “An Experimental Field Study of Interpersonal Discrimination Toward Muslim Job Applicants.” Personnel Psychology 63(4): 881-806.

Madera, Juan M., Eden B. King, and Michelle R. Hebl. 2012. "Bringing Social Identity to Work: The Influence of Manifestation and Suppression on Perceived Discrimination, Job Satisfaction, and Turnover Intentions." Cultural Diversity and Ethnic Minority Psychology 18(2): 165-170.

McDannell, Colleen. 1995. Material Christianity: Religion and Popular Culture in America. Hartford, CT: Yale University Press.

Miller, Lisa R. and Eric Anthony Grollman. 2015. "The Social Costs of Gender Nonconformity for Transgender Adults: Implications for Discrimination and Health.” Sociological Forum 30(3): 809-831.

Mitroff, Ian I. and Elizabeth A Denton. 1999. A Spiritual Audit of Corporate America: A Hard Look at Spirituality, Religion, and Values in the Workplace. San Francisco: Jossey-Bass Inc. 
Mythen, Gabe, Sandra Walklate and Fatima Khan. 2009. “'I’m a Muslim, but I'm not a Terrorist': Victimization, Risky Identities and the Performance of Safety.” British Journal of Criminology 49: 736-754.

Pavalko, Eliza K., Krysia N. Mossakowski, and Vanessa J. Hamilton. “Does Perceived Discrimination Affect Health? Longitudinal Relationships between Work Discrimination and Women's Physical and Emotional Health.” Journal of Health and Social Behavior 44(1): 18-33.

Pedulla, David S. and Sarah Thebaud. 2015. "Can We Finish the Revolution? Gender, WorkFamily Ideals, and Institutional Constraint.” American Sociological Review 80(1): 116139.

Peek, Lori. 2010. Behind the Backlash: Muslim Americans after 9/11. Philadelphia: Temple University Press.

Pettigrew, Thomas F. 1998. "Intergroup Contact Theory.” Annual Review of Psychology 49: 6585.

Putnam, Robert D. and David E. Campbell. 2010. American Grace: How Religion Divides and Unites Us. New York: Simon \& Schuster.

Regression with Stata. UCLA: Statistical Consulting Group. Accessed at http://www.ats.ucla.edu/stat/stata/webbooks/reg/chapter2/statareg2.htm on January 12, 2016.

Rippy, Alyssa and Elana Newman. 2006. "Perceived Religious Discrimination and its Relationship to Anxiety and Paranoia Among Muslim Americans.” Journal of Muslim Mental Health 1(1): 5-20. 
Roberts, Andrea, Margaret Rosario, Natalie Slopen, Jerel P. Calzo and S. Bryn Austin. 2013. "Childhood Gender Nonconformity, Bullying Victimization, and Depressive Symptoms across Adolescence and Early Adulthood: An 11-Year Longitudinal Study.” Journal of the American Academy of Adolescent Psychiatry 52: 143-152.

Shachtman, Noah. 2013. "In Silicon Valley, Meditation is No Fad. It Could Make Your Career." Wired

Smith, Tom W. 2002. "Religious Diversity in America: The Emergence of Muslims, Buddhists, Hindus, and Others.” Journal for the Scientific Study of Religion 41: 577-585.

Smith, Tom W., Peter V. Marsden, and Michael Hout. 2016. General Social Surveys, 1972-2014. Chicago: National Opinion Research Center.

Snape, Ed and Tom Redman. 2003. "Too Old or Too Young? The Impact of Perceived Age Discrimination.” Human Resource Management Journal 13(1): 78-89.

Wallace, Michael, Bradley R.E. Wright, and Allen Hyde. 2014. "Religious Affiliation and Hiring Discrimination in the American South: A Field Experiment." Social Currents 1(2): 189207.

Widner, Daniel and Stephen Chicoine. 2011. 'It's All in the Name: Employment Discrimination Against Arab Americans.” Sociological Forum 26(4): 806-823.

Wright, Bradley R.E., Michael Wallace, John Bailey, and Allen Hyde. 2013. "Religious Affiliation and Hiring Discrimination in New England: A Field Experiment." Research in Social Stratification and Mobility 34: 111-126.

Wuthnow, Robert. 2004. "The Challenge of Diversity." Journal for the Scientific Study of Religion 43: 159-170. 
Religious Discrimination

Wuthnow, Robert. 2005. America and the Challenges of Religious Diversity. Princeton, N.J.: Princeton University Press.

Wuthnow, Robert and Conrad Hackett. 2003. "The Social Integration of Practitioners of NonWestern Religions in the United States." Journal for the Scientific Study of Religion 42: $651-667$. 
Figure 1-Percentage of Respondents Perceiving at Least Some Religious Discrimination in the Workplace by Religious Tradition $(\mathrm{N}=9,723)$

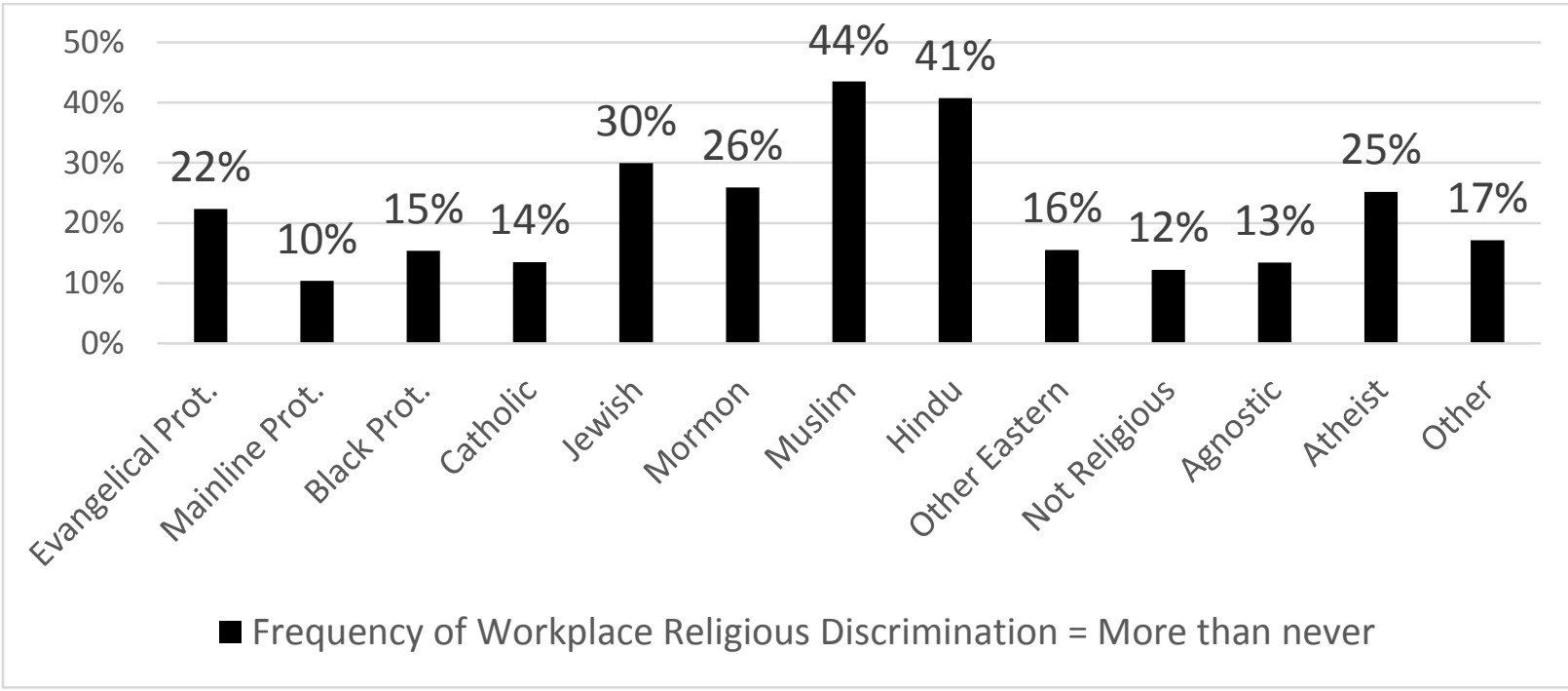




\section{Religious Discrimination}

Table 1 - Descriptive Statistics (N=9,723)

\begin{tabular}{|c|c|c|c|c|}
\hline & $\begin{array}{c}\text { Mean or } \\
\text { Percentage }\end{array}$ & $\begin{array}{l}\text { Lin. Std. } \\
\text { Err. }\end{array}$ & Min & Max \\
\hline \multicolumn{5}{|l|}{ Perceived workplace religious discrimination } \\
\hline Never & $83 \%$ & & & \\
\hline More than never & $17 \%$ & & & \\
\hline How often religion comes up at work & 1.96 & .012 & 1 & 4 \\
\hline \multicolumn{5}{|l|}{ Religious Tradition } \\
\hline Evangelical Protestant & $25.86 \%$ & & & \\
\hline Mainline Protestant & $14.36 \%$ & & & \\
\hline Black Protestant & $4.70 \%$ & & & \\
\hline Catholic & $23.76 \%$ & & & \\
\hline Jewish & $1.87 \%$ & & & \\
\hline Mormon & $1.83 \%$ & & & \\
\hline Muslim & $0.32 \%$ & & & \\
\hline Hindu & $0.73 \%$ & & & \\
\hline Other Eastern & $1.25 \%$ & & & \\
\hline Not Religious & $7.58 \%$ & & & \\
\hline Agnostic & $4.20 \%$ & & & \\
\hline Atheist & $4.18 \%$ & & & \\
\hline Something else & $9.35 \%$ & & & \\
\hline $\begin{array}{l}\text { How often talking to people of different religion } \\
\text { about your religious views }\end{array}$ & 1.41 & .009 & 1 & 4 \\
\hline Religious person & 2.54 & .013 & 1 & 4 \\
\hline Attendance & 4.13 & .036 & 1 & 9 \\
\hline Prayer & 7.10 & .050 & 1 & 11 \\
\hline Reading sacred books & 3.62 & .037 & 1 & 9 \\
\hline \multicolumn{5}{|l|}{ Current Work Status } \\
\hline Working as employee & $51.09 \%$ & & & \\
\hline Self-employed & $6.55 \%$ & & & \\
\hline Unemployed, looking for work & $7.99 \%$ & & & \\
\hline Not working, retired & $17.54 \%$ & & & \\
\hline Not working, disabled & $7.05 \%$ & & & \\
\hline Not working, other reason & $9.77 \%$ & & & \\
\hline Education & 2.76 & .013 & 1 & 4 \\
\hline Income & 11.79 & .062 & 1 & 19 \\
\hline Age & 3.75 & .023 & 1 & 7 \\
\hline Female & $51.79 \%$ & & & \\
\hline \multicolumn{5}{|l|}{ Race } \\
\hline White, Non-Hispanic & $67.82 \%$ & & & \\
\hline Black, Non-Hispanic & $10.60 \%$ & & & \\
\hline Other, Non-Hispanic & $7.47 \%$ & & & \\
\hline Hispanic & $14.10 \%$ & & & \\
\hline
\end{tabular}




\section{Religious Discrimination}

Table 2 - Results from Logistic Regressions Predicting Respondents' Perception of Workplace Religious Discrimination (0=Never; 1=More than Never; N=9,723; Odds Ratios Shown)

\begin{tabular}{|c|c|c|c|}
\hline & $\begin{array}{c}\text { Model } 1 \\
\text { Religion in } \\
\text { Workplace }\end{array}$ & $\begin{array}{c}\text { Model 2 } \\
\text { + Individual's Religion } \\
\text { Tradition, Religious } \\
\text { Expression \& } \\
\text { Religiosity } \\
\end{array}$ & $\begin{array}{c}\text { Model 3 } \\
+ \text { Religion in Workplace } \\
\text { X Religious Tradition }\end{array}$ \\
\hline How Often Religion Comes Up at Work & $2.30 * *$ & $1.94 * *$ & $1.51 * *$ \\
\hline \multicolumn{4}{|l|}{ Religious Tradition } \\
\hline Mainline Protestant & -- & $.66^{* *}$ & $.39 * *$ \\
\hline Black Protestant & -- & $.57 *$ & .61 \\
\hline Catholic & -- & .89 & $.50 * *$ \\
\hline Jewish & -- & $3.14 * *$ & $2.95 * *$ \\
\hline Mormon & -- & .87 & 1.22 \\
\hline Muslim & -- & $3.14^{*}$ & 3.05 \\
\hline Agnostic & -- & 1.13 & $.23 * *$ \\
\hline Atheist & -- & $2.14 * *$ & .59 \\
\hline Something else & -- & .96 & $.62 *$ \\
\hline Religious person & -- & 1.11 & 1.12 \\
\hline Attendance & -- & $1.05^{*}$ & $1.05 *$ \\
\hline Prayer & -- & $.95 * *$ & $.95 * *$ \\
\hline Reading sacred books & -- & $1.10 * *$ & $1.11 * *$ \\
\hline How often talk to others about religion & -- & $1.41 * *$ & $1.38 * *$ \\
\hline \multicolumn{4}{|l|}{ Current Work Status } \\
\hline Income & $.96 * *$ & $.96 * *$ & $.96 * *$ \\
\hline Age & $.90 * *$ & $.91 * *$ & $.90 * *$ \\
\hline Female & $.82 *$ & $.82 *$ & $.83 *$ \\
\hline \multicolumn{4}{|l|}{ Race } \\
\hline White, Non-Hispanic (ref.) & -- & -- & -- \\
\hline Black, Non-Hispanic & .96 & 1.03 & 1.00 \\
\hline Other, Non-Hispanic & $1.71 * *$ & $1.71 * *$ & $1.70 * *$ \\
\hline Hispanic & 1.31 & 1.27 & 1.26 \\
\hline \multicolumn{4}{|l|}{ Religion Comes Up X Religious Tradition } \\
\hline Comes up X Evangelical Protestant (ref.) & -- & -- & -- \\
\hline Comes up X Mainline Protestant & -- & -- & $1.41 * *$ \\
\hline Comes up X Black Protestant & -- & -- & .99 \\
\hline Comes up X Catholic & -- & -- & $1.48 * *$ \\
\hline Comes up X Jewish & -- & -- & .94 \\
\hline Comes up X Mormon & -- & -- & .81 \\
\hline Comes up X Muslim & -- & -- & .91 \\
\hline Comes up X Hindu & -- & -- & 1.91 \\
\hline Comes up X Other Eastern & -- & -- & $2.60 *$ \\
\hline Comes up X Not Religious & -- & -- & $1.72 * *$ \\
\hline
\end{tabular}




\section{Religious Discrimination}

Comes up X Agnostic

Comes up X Atheist

Comes up X Something else

$* \mathrm{p}>.05 ; * * \mathrm{p}<.01$
$3.19^{* *}$

$2.67 * *$

$1.37 *$ 
Religious Discrimination

Table 3-Predicted probability of perceiving workplace religious discrimination by religious tradition and frequency of religion coming up at work (Based on model 4 in table 2, other predictors held at mean)

\begin{tabular}{|c|c|c|c|}
\hline \multirow[b]{2}{*}{ Religious Tradition } & \multicolumn{2}{|c|}{$\begin{array}{c}\text { How Often Religion Comes Up } \\
\text { at Work }\end{array}$} & \multirow[b]{2}{*}{ Ratio } \\
\hline & Never & Very Often & \\
\hline Evangelical Protestant & 10.49 & 28.91 & 2.75 \\
\hline Mainline Protestant & 4.47 & 31.5 & 7.04 \\
\hline Black Protestant & 6.76 & 19.65 & 2.90 \\
\hline Catholic & 5.61 & 40.43 & 7.20 \\
\hline Jewish & 25.75 & 50.67 & 1.96 \\
\hline Mormon & 12.54 & 21.49 & 1.71 \\
\hline Muslim & 26.35 & 48.48 & 1.83 \\
\hline Hindu & 11.50 & 75.97 & 6.60 \\
\hline Other Eastern & 1.90 & 54.29 & 28.57 \\
\hline Not Religious & 6.86 & 56.59 & 8.24 \\
\hline Agnostic & 2.70 & 75.78 & 28.06 \\
\hline Atheist & 6.54 & 82.33 & 12.58 \\
\hline Other & 6.78 & 39.41 & 5.81 \\
\hline Overall & 8.72 & 24.91 & 2.85 \\
\hline
\end{tabular}

